\title{
PENGEMBANGAN MODEL PERMAINAN PRA-CALISTUNG ANAK USIA DINI
}

\author{
SUGIONO ${ }^{1}$, KUNTJOJO ${ }^{2}$ \\ Prodi Bimbingan Konseling Universitas Nusantara PGRI Kediri \\ Jalan K.H. Achmad Dahlan 76 Kediri \\ Telp. \& Fax: (0354) 771576 \\ Email: Sugiono_unp@yahoo.co.id ${ }^{1}$, muzkunt@gmail.com²
}

\begin{abstract}
This research was conducted to produce an effective play model for developing literacy and numeracy in early childhood. The method used in this study is research and development based on the model of Borg and Gall. The resulting play model called Let's Find Them. Limited test of play model was done in Permata Pelangi Kediri kindergarten on May 2, 2016 and more extensive trial was held in ABA 6 Kediri kindergarten on May 16, 2016. Test the effectiveness of model was held in Pembina Kediri state kindergarten on June 2, 2016 and in Dharma wanita ngampel Kediri kindergarten on June 3, 2016. The results of data analysis showed that there were significant differences in the competencies between the time before and after the play model is applied with significantly 0,00. The conclusion is the play model Let's Find Them is very effective for developing literacy and numeracy in early childhood.
\end{abstract}

Keywords: play model, literacy, numeracy, early childhood

\begin{abstract}
Abstrak: Penelitian ini dilakukan untuk menghasilkan model permainan yang efektif untuk mengembangkan kemampuan pra-calistung anak usia dini. Metode penelitian yang digunakan dalam penelitian ini adalah metode penelitian dan pengembangan berdasarkan pada model Borg and Gall. Model permainan hasil pengembangan diberi sebutan Bermain Ayo Kita temukan. Ujicoba terbatas model permainan dilakukan di TK Permata Pelangi Kediri pada tanggal 2 Mei 2016 dan ujicoba lebih luas dilakukan di TK ABA 6 Kediri pada tanggal 16 Mei 2016. Uji efektivitas dilaksanakan di TK Negeri Pembina Kota Kediri pada tanggal 2 Juni 2016 dan TK Dharma Wanita Ngampel Kota Kediri pada tanggal 3 Juni 2016. Data dianalisis menggunakan uji Paired Samples $t$ Test. Hasil analisis menunjukkan bahwa ada perbedaan yang signifikan dalam kemampuan pra-calistung antara waktu sebelum dan sesudah diterapkan model permainan dengan signifikansi 0,00. Kesimpulannya bahwa model bermain Ayo Kita Temukan terbukti efektif untuk mengembangkan kemampuan pracalistung anak usia dini.
\end{abstract}

Kata kunci: model permainan, pra-calistung, anak usia dini

Masa usia dini $(0-6$ tahun $)$ merupakan masa keemasan (golden age). Pada masa ini stimulasi seluruh aspek perkembangan berperan penting untuk tugas perkembangan
selanjutnya.
Masa
usia
dini
merupakan
merupakan
masa
terpenting dalam rentang kehidupan seseorang karena pada masa ini terjadi proses pertumbuhan dan 
perkembangan yang sangat cepat. Menurut para ahli neurosain masa usia dini merupakan masa pembentukan jaringan sel otak dan terjadinya sangat cepat (Direktorat Pembinaan Anak Usia Dini, 2015:6). Berkenaan dengan hal itu stimulasi intensif dari lingkungan pendidikan sangat diperlukan agar anak bisa berkembang secara optimal.

Perkembangan secara optimal hanya bisa terwujud jika dilakukan upaya pembinaan yang terencana, holistik, intensif, didasarkan pada karakteristik perkembangan. Upaya pembinaan yang ditujukan kepada anak sejak lahir sampai dengan usia 6 tahun yang dilakukan melalui pemberian rangsangan pendidikan untuk membantu pertumbuhan dan perkembangan jasmani dan rohani agar anak memiliki kesiapan dalam memasuki pendidikan lebih lanjut disebut sebagai pendidikan anak usia dini atau lebih dikenal dengan PAUD (Sujiono, 2009: 8).

Program PAUD untuk mengembangkan seluruh potensi anak yang mencakup lingkup perkembangan nilai agama dan moral, fisik motorik, kognitif, bahasa, sosial emosional, dan seni (Direktorat Pembinaan Anak Usia Dini, 2015:1). Pengembangan berbagai potensi anak usia dini yang dilakukan secara struktur dan melembaga dilaksanakan menggunakan kurikulum yang pada saat ini dikenal dengan Kurikulum 2013 PAUD. Salah satu karakteristik Kurikulum $2013 \quad$ adalah menggunakan pembelajaran tematik.

Dalam model pembelajaran tematik mengakomodasi pengenalan konten nilai agama dan moral, alam, kehidupan, manusia, budaya, dan simbol melalui kegiatan yang terpadu dan kontekstual untuk mewujudkan kematangan selaras dengan lingkup perkembangan

(Direktorat Pembinaan Anak Usia Dini, 2015: 20 $-21)$.

Anak usia dini memiliki karakteristik tertentu dalam belajar. Salah satu karakteristik cara belajar anak adalah anak belajar melalui bermain. Atas dasar karakteristik tersebut maka dalam pembelajaran untuk anak usia dini berlaku prinsip bermain sambil belajar dan belajar seraya bermain. Bermain disesuaikan dengan perkembangan anak dimulai dari bermain sambil belajar (unsur 
Pengembangan Model Permainan . .

Sugiono, Kuntjojo

bermain lebih besar) dan ke belajar seraya bermain (unsur belajar lebih besar).

Bermain, bagi anak selain mendatangkan kegembiraan juga merupakan proses belajar yang menyebabkan terjadinya perkembangan pada berbagai aspek. Hal ini membawa konsekuensi bahwa bermain hendaknya dilakukan sebagai metode pengembangan dan bukan hanya sebagai selingan kegiatan belaka. Sebagai metode pengembangan, bermain hendaknya dikelola dengan sebaik-baiknya. Guru sebagai pengelola proses belajar pembelajaran semestinya mampu memilih jenis permainan yang tepat untuk perkembangan anak dan mampu pula menerapkannya dalam proses belajar pembelajaran.

Untuk keperluan tersebut diperlukan model permainan yang sesuai dengan karakteristik perkembangan anak, dapat dilaksanakan di kelas, di luar kelas, mapun di luar sekolah agar setiap anak mengalami perkembangan nilai agama dan moral, fisik motorik, kognitif, bahasa, sosial emosional, dan seni sesuai dengan yang digariskan dalam program PAUD.

Fakta yang ditemukan selama observasi lapangan menunjukkan bahwa ada masalah berkenaan dengan pelaksanaan atau penerapan kegiatan bermain di TK. Pertama, masih ada sebagin guru yang menganggap kegiatan bermain yang diterapkan di kelas hanya sebagai selingan dan bukan sebagai metode pengembangan. Kedua, kegiatan bermain hanya dilakukan untuk mengembangkan kemampuan tertentu saja, dan belum diarahkan untuk mengembangkan berbagai bidang pengembangan.

Bertolak dari masalah tersebut peneliti tertarik untuk mengembangkan suatu model permainan untuk anak usia dini. Model adalah rencana, representasi, atau deskripsi yang menjelaskan suatu objek, sistem, atau konsep, yang seringkali berupa penyederhanaan atau idealisasi (Wikipedia, 2015). Model permainan merupakan diskripsi konsep, tujuan, dan langkahlangkah bermain yang didasarkan pada teori-teori tertentu. Model permainan yang akan dikembangkan 
dalam penelitian ini adalah model permainan untuk mengembangkan berbagai kemampuan anak usia dini, khususnya peserta didik TK, didasarkan pada teori-teori belajar, khususnya teori belajar konstruktivistik, teori belajar joyful learning, teori quantum learning/ quantum teaching, prinsip PAKEM (Pembelajaran, Aktif, Kreatif, Efektif, dan Menyenangkan), dan teori tentang perkembangan anak. Selain itu pengembangan model permainan juga didasarkan pada kemudahan dalam pelaksanaannya, bisa dilakukan di dalam kelas, di luar kelas, maupun di luar sekolah.

Penelitian ini dibatasi hanya pada satuan pendidikan anak usia dini jalur pendidikan formal dan yang menjadi subjek penelitian adalah anak kelompok B Taman Kanak-kanak. Adapun bidang pengembangan yang akan diteliti adalah bidang pengembangan kemampuan berbahasa, khususnya kemampuan permulaan membaca dan menulis (literasi), dan bidang pengembangan kognitif, khususnya permulaan kemampuan berhitung. Tiga bidang kemampuan tersebut dikenal dengan sebutan kemampuan pra-calistung.

Berdasarkan paparan latar belakang masalah dan pembatasan masalah maka yang menjadi fokus dalam penelitian ini adalah pengembangan model permainan yang fungsioanal untuk mengembangkan kemampuan permulaan membaca, permulaan menulis dan permulaan berhitung anak kelompok B Taman Kanak. Berkaitan dengan fokus permasalahan tersebut maka rumusan masalah dalam penelitian ini adalah sebagai berikut.

1. Metode bermain atau model permainan apa saja yang digunakan para guru TK Kelompok B untuk mengembangkan kemampuan permulaan membaca, menukis, dan berhitung dan apa saja yang dijadikan pertimbangan guru dalam menggunakan model permainan, dan adakah hambatan dalam menggunakan model permainan tersebut?

2. Model permainan yang bagaimanakah yang secara teoritis dapat meningkatkan 
Pengembangan Model Permainan . .

Sugiono, Kuntjojo

\begin{tabular}{lrr} 
kemampuan & \multicolumn{2}{c}{ permulaan } \\
membaca, & menuklis, dan \\
berhitung & peserta didik \\
kelompok B & Taman & Kanak- \\
kanak?”. & & \\
Seberapa efektif model tersebut \\
untuk & mengembangkan \\
kemampuan & \multicolumn{2}{c}{ permulaan } \\
membaca, & menulis & dan \\
berhitung & peserta & didik \\
kelompok B & Taman & Kanak- \\
kanak? & &
\end{tabular}

\section{Bermain dan Perkembangan Anak}

Hampir setiap anak, di seluruh dunia, melakukan aktivitas memainkan, dorongan untuk bermain begitu kuat, bahwa anak-anak akan melakukannya ketika mereka tidak memiliki mainan, ketika orang tua tidak aktif memberikan motivasi, dan bahkan ketika mereka di tengahtengah zona perang (White, 2012: 5). Begitu kuatnya hubungan anak-anak dengan bermain sehingga bisa dikatakan bahwa bermain adalah bagian dari kehidupan anak.

Bahwa anak-anak yang sehat selalu mempunyai dorongan untuk bermain. Mereka menggunakan sebagian waktu dan energinya untuk bermain. Hasil penelitian menunjukkan bahwa bermain merupakan bagian tak terpisahkan dari masyarakat di mana anak-anak dilahirkan dan mengalami sosialisasi. Berkenaan dengan hal tersebut Whitebread menyatakan sebagai berikut.

The archaelogical, historical, anthropological research into children's play is hows that play is ubiquitous in human societies, and children play is suppoted by adult in cultures by the manufacture of play equipment and toys (Whitebread, 2012: 9).

Anak-anak memerlukan waktu yang cukup banyak untuk mengembangkan dirinya melalui bermain. Dengan bermain, anak-anak mendapatkan manfaat yang besar, yaitu: (1) bermain memicu kreativitas, (2) bermain mencerdaskan otak, (3) bermain bermanfaat untuk mengatasi konflik, (4) bermain bermanfaat untuk melatih empati, (5) bermain bermanfaat untuk melatih panca indra, (6) bermain sebagai media terapi, (7) bermain bermanfaat untuk melakukan penemuan (Montolalu, 2007, 1.15 1.17). 
Hasil dari berbagai penelitian menunjukkan bahwa bermain selain memiliki fungsi rekreatif juga fungsi perkembangan. Dalam bermain, anak bukan sekadar bergerak dan menggunakan alat permainan tetapi di dalamnya ada proses pembelajaran yang sangat berguna untuk perkembangan berbagai aspek pada anak. Oleh karena itu dengan bermain anak-anak dapat mengalami suatu proses yang oleh Russ (2004: 1) dinyatakan sebagai fundamental play processes karena dengan bermain anak-anak mengalami proses perkembangan pada berbagai dan juga merupakan proses psikoterapi.

$\begin{array}{crr}\text { Bermain, } & \text { terutama } & \text { yang } \\ \text { dilakukan } & \text { secara } & \text { bersama }\end{array}$ memberikan kontribusi pada berbagai fungsi perkembangan, termasuk perkembangan kesehatan psikologis. Gray (2011: 458) menyatakan bahwa jika anak-anak tidak berkesempatan bermain bersama anak-anak lainnya maka mereka gagal memperoleh keterampilan sosial dan emosional yang penting untuk perkembangan kesehatan psikologis.

\section{Belajar Melalui Bermain}

Anak usia dini adalah individuindividu yang sedang mengalami perkembangan dalam semua aspek. Perkembangan secara optimal dan lancar terjadi jika anak-anak mengalami proses belajar yang menyenangkan yang berlangsung melalui bermain. Para pakar neurosains telah mempelajari bagaimana otak manusia berkembang dan berfungsi, dan bagaimana pikiran manusia terbentuk. Hasil penelitian mereka menunjukkan bahwa anakanak memiliki motivasi yang tinggi, pembelajar yang cerdas, yang aktif mencari interaksi dengan orang-orang di sekitar mereka dan menghendaki untuk bermain dengannya (Departement for Children, School, and Families, 2009: 6).

Bermain memiliki multi fungsi bagi proses belajar dan perkembangan anak. Berkenaan dengan hal tersebut Sutton-Smith, seorang teoris bermain menyatakansebagai berikut.

"Not only are children developing the neurological foundations that will enable problem solving, language and creativity, they are also learning while they are playing, they are learning how to relate to others, how to calibrate their muscles and bodies and how to think in 
Pengembangan Model Permainan . .

Sugiono, Kuntjojo

abstract terms. Through their play children learn how to learn (Goldstein, 2012: 5).

Bagi Sutton-Smith, bermain bukan hanya mengembangkan landasan neurologis untuk memecahkan masalah, bahasa, dan kreativitas melainkan lebih dari itu. Melalui bermain, anak-anak belajar berinteraksi dengan teman-temannya, melalui bermain anak-anak juga belajar bagaimana mengfungsikan dan tubuh, cara berpikir secara abstrak dan belajar bagaimana belajar.

Membahas peran bermain dalam belajar, White (2012: 7), menyatakan bahwa bermain adalah proses sepanjang hayat dan pondasinya terbentuk melalui bermain pada masa usia dini. Besarnya kontribusi bermain dalam belajar adalah berkembangnya kebiasaan positif untuk belajar.

\section{Pengelolaan Kegiatan Bermain}

Dalam konteks pendidikan anak usia dini formal bermain pada dasarnya merupakan bagian integral dari lingkungan akademik. Hal ini membawa konsekuensi bahwa kegiatan bermain hendaknya dikelola dengan sebaik mungkin. Untuk keperluan tersebut pendidik hendaknya memperhatikan densitas dan intensitas bermain dengan didasarkan pada kebutuhan akan perkembangan anak. Densitas (density) adalah berbagai macam cara bermain yang disediakan untuk mendukung pengalaman anak dan intensitas (intensity) adalah sejumlah waktu yang dibutuhkan untuk bermain (Latif, dkk., 2013: 78). Pengelolaan bermain dari sisi densitas menyangkut pemilihan jenis permainan dan menyiapkan lingkungan bermain yang sesuai dengan karakteristik dan kebutuhan perkembangan anak.

Kegiatan bermain yang dilakukan oleh anak-anak dapat menjadi efektif bagi perkembangan mereka bila pendidik bisa melakukan perannya dengan baik. Peran pendidik dalam dalam kegiatan bermain yang dilakukan oleh anak-anak, pada lembaga pendidikan pendidikan anak usia dini adalah sebagai:

perencana, (2) fasilitator, pengamat, (4) model, (5) motivator, dan (6) teman (Montolalu, 2005: 12.5 $-12.7)$. 
Guru, dalam perannya sebagai perencana, bertanggung jawab dalam pemilihan jenis kegiatan bermain, menyiapkan sarana dan prasarana yang diperlukan, dan mengelola kegiatan bermain. Berkenaan dengan peran guru sebagai perencana dalam kegiatan bermain oleh anak-anak, ada dua peran guru dalam menyiapkan lingkungan bermain, yaitu: organizing dan resourcing (Aistear: 2013: 57 - 58). Organizing, meliputi: (1) Interest area: mencakup pemilihan tempat dan penataan ruang untuk bermain, (2) Social and personal space: mencakup pengorganisasian kegiatan bermain, apakah dilakukan anak seorang diri, berpasangan, kelompok kecil, atau kelompok besar, (3) Outdoor/indoor: pengorganisasian bermain dengan mempertimbangkan apakah permainan dilakukan di dalam atau di luar kelas, bahkan diluar sekolah, (4) Display: pengorganisasian bermain menyusun display, dan (5) Storage: penempatan alat permainan di tempat yang tepat, sehingga anak-anak mudah untuk mengambil dan mengembalikannya.
Peran resourcing guru dalam kegiatan bermain peserta didik meliputi: (1) Diversity resources: Penggunaan media dan alat-alat permainan yang beraneka ragam, (2) Special resources: Pemilihan media, alat-alat permainan yang disesuaikan dengan kebutuhan, (3) Literacy and numeracy resources: Penyediaan media dan alat permainan yang berguna untuk pengembangan literasi dan konsep bilangan, (4) Open and ended materials: Pemilihan media dan alat-alat permainan dengan mempertimbangkan faktor ukuran besar - kecil, bahan baru atau daur ulang, benda alami atau tiruan, (5) Sufficient resources: Pemilihan media dan alat-alat permainan dengan mempertimbangkan peran serta anakanak dalam bermain, dan (6) Handson experiences: Pemilihan aktivitas, apakah anak menyentuh, membau, mendengar, melihat, dst.

\section{Pengembangan Literasi dan Numerasi Anak Usia Dini}

Membaca dan menulis dalam konteks kurikulum anak usia dini sering dinyatakan dengan keaksaraan atau literasi dan termasuk dalam bidang pengembangan bahasa. 
Pengembangan Model Permainan . .

Sugiono, Kuntjojo

Kriteria minimal tentang kualifikasi perkembangan anak dalam Kurikulum 2013 Pendidikan Anak Usia Dini (K13 PAUD) dinyatakan dengan Standar Tingkat Pencapaian Perkembangan (STPP). STTP untuk kemampuan keaksaraan berdasarkan K13 PAUD adalah memahami hubungan bentuk dan bunyi huruf, meniru bentuk huruf, serta memahami kata dalam cerita (Direktorat Pembinaan Anak Usia Dini, 2015²: 32).

Kemampuan berhitung atau numerasi dalam kurikulum pendidikan anak usia dini termasuk dalam bidang pengembangan kognitif. STTP untuk kemampuan numerasi berdasarkan K13 PAUD adalah berpikir simbolik yang mencakup: mengenal, menyebutkan, dan menggunakan lambang bilangan $1-10$, mengenal abjad serta mampu merepresentasikan benda dalam bentuk gambar (Direktorat Pembinaan Anak Usia Dini, 2015²: $31)$.

Literasi dan numerasi merupakan keterampilan esential bagi manusia oleh karena itu kemampuan ini harus dikembangkan sejak anak usia dini.
Pengembangan kemampuan tersebut antara lain belajar melalui bermain. Belajar melalui bermain merupakan aktivitas yang memiliki perang sangat penting dalam perkembangan literasi dan numerasi anak usia dini.

\section{Tujuan Penelitian}

Penelitian dengan judul Pengembangan Model Permainan Persiapan Belajar Pra-Calistung Anak TK dilakukan untuk mencapai beberapa tujuan sebagai berikut.

1. Mendeskripsikan kondisi awal pembelajaran pengembangan kemampuan permulaan membaca, menulis dan berhitung peserta didik kelompok B Taman Kanak-kanak saat ini.

2. Merancang model permainan yang secara teoritis efektif untuk mengembangkan kemampuan permulaan membaca, menulis, dan berhitung peserta didik Kelompok B TamanKanakkanak

3. Menguji efektivitas model permainan untuk mengembangkan kemampuan permulaan membaca, menulis, dan berhitung peserta didik 
Kelompok B Taman Kanak- memperhatikan esensi yang harus kanak.

dipenuhi dalam pelaksanaan penelitian sehingga siklusnya terdiri

\section{METODE PENELITIAN}

Penelitian ini dilakukan untuk menghasilkan produk berupa model permainan yang efektif untuk mengembangkan kemampuan pramembaca, pra-menulis, dan berhitung anak usia dini. Untuk dapat menghasilkan produk tertentu digunakan penelitian yang bersifat analisis kebutuhan dan untuk menguji keefektifan produk tersebut supaya dapat berfungsi di masyarakat luas, maka diperlukan penelitian untuk menguji produk tersebut (Sugiyono, 2013: 297). Berkenaan dengan hal tersebut maka desain yang dipilih dalam penelitian ini adalah metode penelitian dan pengembangan (research and development).

Tahapan dalam penelitian ini diadaptasi dari sepuluh langkah penelitian dan pengembangan sebagaimana dikemukakan Borg dan Gall (Sukmadinata, 2012: 169 - 170) dan dalam penelitian ini disesuaikan dengan kebutuhan dengan tetap atas: (1) Studi pendahuluan, mempelajari kondisi yang ada di lapangan, teori-teori yang relevan, dan hasil penelitian yang berkaitan dengan produk yang akan dikembangkan, (2) Merencanakan dan mengembangkan produk awal berdasarkan hasil penelitian pendahuluan, (3) Melakukan ujicoba di lapangan secara terbatas dan lebih luas dimana natinya produk akan digunakan, diantara langkah ini dilakukan revisi terhadap kelemahankelemahan yang ditemukan dalam setiap uji coba di lapangan, dan (4) Validasi model yang dikembangkan sampai memperoleh produk akhir sebagai sebuah model pembelajaran. Kegiatan pengembangan dan uji validasi produk dilakukan secara siklus, disertai umpan balik, evaluasipenilaian dan perbaikan.

Tahapan penelitian selanjutnya divisualisasikan dalam bentuk bagan alur sebagai berikut. 


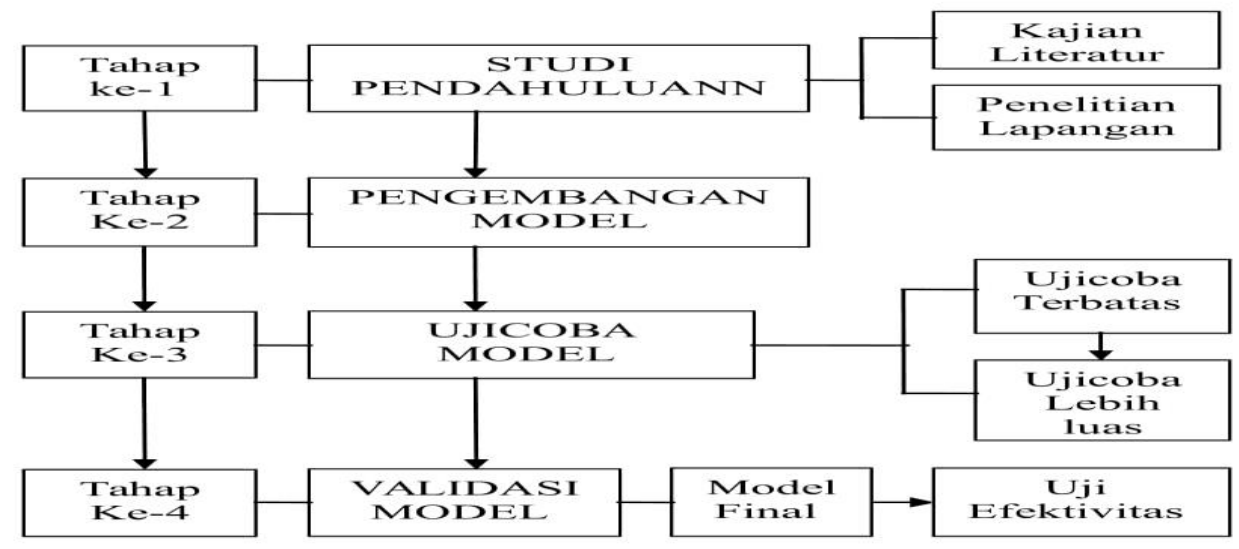

Bagan 1. Tahapan Penelitian dan Pengembangan

Penelitian ini dilakukan di Taman Kanak-kanak (TK) yang merupakan salah satu lembaga pendidikan anak usia dini jalur pendidikan formal dengan mengambil lokasi di Kediri Propinsi Jawa Timur. Dari seluruh lembaga TK yang ada di Kota Kediri selanjutnya dipilih 5 (lima) TK yang tersebar di 3 (tiga) kecamatan untuk yaitu TK Negeri Pembina Kota Kediri, TK Negeri Pembina Kecamatan Mojoroto Kota Kediri, dan TK Dharma Wanita Ngampel Kecamatan Mojoroto Kota Kediri, TK ABA 6 Kecamatan Mojoroto Kota Kediri, dan TK Permata Pelangi Bence Kecamatan Pesantren Kota Kediri.

Ujicoba terbatas model permainan dilakukan di TK Permata Pelangi Kota Kediri dengan subjek penelitian peserta didik Kelompok B dan ujicoba lebih luas dilakukan di TK ABA 6 Mojoroto Kota Kediri dengan mengambil subjek penelitian peserta didik Kelompok B1 dan B2. Uji efektivitas dilakukan di TK Negeri Pembina Kota Kediri dengan subjek penelitian peserta didik Kelompok B1, B2, dan B3, dan TK Dharma Wanita Ngampel Kota Kediri dengan subjek penelitian peserta didik Kelompok B1 dan B2.

Beberapa teknik dan instrumen yang diperlukan sesuai dengan kebutuhan penelitian, yaitu sebagai berikut. (1) Teknik observasi, dipilih untuk mendapatkan data berupa pengamatan secara langsung terhadap responden selama kegiatan pembelajaran. Objek yang diobservasi berupa aktivitas tentang 
proses penerapan model permainan dalam mencapai tujuan yang dilakukan secara berkesinambungan sampai diperoleh data yang memadai. (2) Teknik angket, digunakan untuk memperoleh data yang diperlukan dari pendidik dan pengelola untuk mendapatkan informasi tentang pelaksanaan pelaksanaan pembelajaran pada tahap awal penelitian. (3) Teknik dokumentasi, digunakan untuk memperoleh data tertulis yang berhubungan dengan proses dan hasil belajar yang sudah terdokumentasikan oleh pihak sekolah dan pihak lainnya, yang diperlukan dalam penelitian.

Teknik analisis data yang digunakan berdasarkan tahapan penelitian ini adalah: (1) analisisis deskriptif kuantitatif, (2) analisis deskriptif kualitatif, dan (3) analisis statistik inferensial. Analisis data tahap penelitian pendahuluan adalah analisis deskriptif. Dengan teknik ini didiskripsikan aspek-aspek yang terkait dengan pengembangan kemampuan permulaan membaca, menulis, dan berhitung di Taman Kanak-kanak. Temuan yang diperoleh dari survai lapangan selanjutnya ditelaah dalam hubungannya dengan kurikulum yang berlaku di TK saat ini dan juga teoriteori dan konsep-konsep tentang bermain dan perkembangan anak usia dini.

Analisis data pada tahap pengembangan dan ujicoba dan validasi model adalah analisis deskriptif kualitatif. Data yang diperoleh pada tahap ini dianalisis melalui tahapan proses sebagai berikut: (1) reduksi data, (2) pemaparan data, dan (3) penarikan kesimpulan. Analisis data untuk menguji efektivitas model permainan adalah analisis statistik inferensial khususnya uji paired samples $t$ test. Data yang diperoleh pada saat eksperimen meliputi skor test awal yang dilaksanakan sebelum model diterapkan dan skor test akhir yang dilaksanakan setelah model diterapkan. Data tersebut selanjutnya dianalisis untuk mengetahui pengaruh model permainan yang dikembangkan terhadap pembentukan kesiapan belajar membaca menulis anak usia dini dengan menggunakan Uji-t untuk melihat perbedaan hasil test awal dan 
Pengembangan Model Permainan . .

Sugiono, Kuntjojo

tes akhir dengan menggunakan program SPSS Versi 21.

\section{HASIL PENELITIAN DAN PEMBAHASAN}

\section{Pengembangan Kemampuan}

\section{Pra-calistung}

Pengumpulan data dilakukan pada tanggal 16, 17 dan 18 April 2015 di TK Negeri Pembina Kota Kediri, TK Negeri Pembina Kecamatan Mojoroto, dan TK Dharma Wanita Kelurahan Ngampel Kecamatan Mojoroto Kota Kediri. Hasil pengumpulan data tentang pengembangan kemampuan membaca melalui metode bermain didiskripsikan dalam uraian berikut. Dari 11 responden yang berasal dari 3 TK yang berbeda menunjukkan bahwa $\quad 72,72 \%$ responden menerapkan metode bermain dengan jenis permainan yang berbeda. Metode-metode bermain tersebut pada umumnya merupakan metode yang sudah biasa diterapkan di TK diantaranya bermain susun huruf, bermain tebak kata, dan bermain ular tangga, dst. Sedangkan 3 orang responden $(27,28 \%)$ menerapkan metode bermain yang sama, yaitu metode bermain susun kata.

Ada bermacam - macam pertimbangan guru dalam pemilihan dan penerapan metode bermain untuk mengembangkan kemampuan membaca Anak Kelompok B TK, yaitu sebagai berikut: menyenangkan bagi anak, mudah pelaksanaannya, media yang diperlukan mudah didapat dan dibuat, merangsang minat belajar anak mengembangkan rasa ingin tahu anak, dan memberi tantangan pada anak.

Hasil pengumpulan data tentang pengembangan kemampuan menulis menggunakan melalui metode bermain dideskripsikan berikut ini. Sebanyak $56 \%$ responden menerapkan metode bermain untuk mengembangkan kemampuan menulis. Metode-metode bermain yang digunakan untuk mengembangkan kemampuan menulis merupakan metode yang juga sudah biasa diterapkan di TK diantaranya bermain salin label, metode eksplorasi kata, metode putaran huruf, metode bermain dadu engklek, metode bermain menggunakan kartu huruf. Sedangkan 
44\% tidak menerapkan metode bermain tetapi metode pemberian tugas dan metode demonstrasi. Pertimbangan guru dalam memilih dan menerapkan metode bermain untuk mengembangkan kemampuan menulis adalah efektivitas metode, menyenangkan bagi anak, dan mudah untuk dilakukan anak, lebih menarik minat anakdanmedia yang diperlukan sederhana.

Metode bermain yang sering dipakai para guru untuk mengembangkan kemampuan berhitung adalah metode bermain balok hitung, metode bermain dadu engklek, metode bermain putaran angka, bermain berhitung dengan barang-barang bekas yang ada disekitar, bermain sambil berhitung benda-benda yang ada di sekitar lingkungan belajar, dan belajar tebak angka dan jumlahnya, serta bermain hitung berantai, bermain dengan menghitung benda sesungguhnya dan bermain ular tangga dengan kartu penjumlahan dan pengurangan.

Pertimbangan guru dalam menggunakan metode bermain untuk mengembangkan kemampuan berhitung pada anak adalah: menyenangkan bagi anak (45\%), efektivitas metode, menarik bagi anak, mudah dilakukan oleh anak (36\%), medianya mudah dibuat, media tersedia secara alami,media mudah didapat, dapat mengembangkan kemampuan bekerja sama, menciptakan situasi kompetitif (19\%).

Sama dengan pengembangan kemampuan menulis, pertimbangan guru dalam memilih dan dan menerapkan metode bermain untuk mengembangan kemampuan berhitung yaitu efektivitas metode, menyenangkan bagi anak, dan menarik minat anak. Semua responden menyatakan bahwa metode bermain yang mereka terapkan berhasil untuk mengembangkan kemampuan berhitung peserta didik.

\section{Pengembangan Model Permainan}

Model permainan hasil pengembangan diberi sebutan "Bermain Ayo Kita Temukan". Dalam permainan ini anak-anak diberi kesempatan untuk menemukan benda-benda yang ciri-cirinya sudah dikenali, huruf-huruf yang membentuk kata dari nama benda- 
Pengembangan Model Permainan . . Sugiono, Kuntjojo

benda tersebut, dan juga menemukan angka-angka yang menyatakan jumlah dari benda-benda yang telah ditemukannya. Permainan ini diterapkan untuk proses pembelajaran dengan beragam tema/subtema.

Kemampuan yang dapat dikembangkan melalui permainan “Ayo Kita Temukan” pada dasarnya semua bidang pengembangan, yaitu: 1) nilai agama dan moral, 2) sosial emosional, 3) kognitif, 4) bahasa, 5) fisik - motorik, dan 6) estetika, namun dalam penelitian ini pengembangkan difokuskan pada kemampuan literasi (membaca dan menulis) dan numerasi (berhitung).

Yang dijadikan acuan dalam pengembangan model Bermain Ayo Kita Temukan adalah: (1) Teori Quantum Teaching dan Quantum Learning, (2) Teori Belajar Konstruktivistik, (3) Teori Joyfull Learning, (4) Prinsip belajar sambil bermain dan bermain seraya belajar, (5) prinsip PAKEM, yaitu pembelajaran yang efektivitas, menyenangkan bagi anak, dan membuat anak-anak aktif dan kreatif dalam belajar.
Alat permainan edukatif atau media yang digunakan untuk "Bermain Ayo Kita Temukan": (1) Satu perangkat Papan A-Ba-Ca, (2) Sebuah Kotak Pintar, yang berisi berbagai bentuk benda atau hewan, huruf dan angka. Benda-benda yang disediakan disesuaikan dengan sumbtema yang menjadi pembahasan, (3) Lembaran kertas, yang berisi gambar-gambar yang sesuai dengan tema pembelajaran untuk menulis, (4) Lembaran kertas putih untuk menulis huruf dan kata (jumlah minimal sebanyak jumlah anak dalam satu kelas).

\section{Ujicoba Model Permainan}

Ujicoba I (ujicoba secara terbatas) model permainan dilakukan pada tanggal 2 Mei 2016. Subjek untuk ujicoba adalah anak Kelompok B TK Permata Pelangi Desa Bence Kecamatan Pesantren Kota Kediri yang berjumlah 16 anak. Berdasarkan hasil observasi selama ujicoba selanjutnya tim peneliti melakukan revisi terhadap model permainan, khususnya pada keberadaan halang rintang yang terlalu mudah dan kurang menarik bagi anak. 
Ujicoba II (ujicoba lebih luas) model permainan dilakukan pada tanggal 16 Mei 2016. Subjek untuk ujicoba adalah anak Kelompok B1 dan B2 TK ABA 6 Mojoroto Kota Kediri yang berjumlah 26 anak (B1) dan 29 anak (B2) . Hasil ujicoba ditindak lanjuti dengan melakukan revisi model permainan, khususnya pada penempatan gambar-gambar, huruf, dan angka perlu disendirikan agar anak tidak mengalami kesulitan ketika harus menemukan objek yang dimaksud dan halang rintang lebih menarik dan menantang serta tidak membutuhkan waktu yang lama untuk menyiapkannya.

\section{Validasi Model Permainan}

Berdasarkan temuan-temuan pada saat ujicoba selanjutnya dilakukan validasi terhadap model permainan, baik itu prosedur pelaksanaan dan property yang digunakan. Berdasarkan temuan selama ujicoba bahwa model permainan dapat dilanjutkan penerapannya melalui model pembelajaran area. Kelompok tertentu dimasukkan ke area seni untuk menggambar, mewarnai, atau menggunting gambar-gambar benda yang sudah dicari dan ditemukan. Kelompok lainya dimasukkan ke araa bahasa uhtuk belajar membaca dan menulis, dan seterusnya.

Berdasarkan temuan ujicoba selanjutnya alat permainan edukatif ditambah dengan "dingklik" untuk ukuran anak. Alat permainan edukatif ini digunakan memberikan halangan dan tantangan kepada anak ketika mereka maju menuju kotak ajaib untuk berusaha menemukan benda-benda yang ciri-cirinya sudah dideskripsikan oleh guru. Aktivitas melewati halang rintang selain dimaksudkan untuk memberi tantangan juga untuk melatih motorik kasar anak. Landasan teoritis model permainan tidak berubah sedangkan mengalami perubahan adalah prosedur bermain dan alat permainan edukatif yang dipergunakan. Deskripsi dan prosedur model permainan "Ayo Kita Temukan" adalah sebagai berikut ini.

\section{Deskripsi Model Permainan}

Permainan ini disusun untuk mengembangkan beberapa aspek perkembangan pada anak usia dini, khususnya untuk peserta didik TK / 
Pengembangan Model Permainan . . Sugiono, Kuntjojo

RA. Model permainan Ayo Kita Temukan dapat dipergunakan untuk mengembangkan semua kemampuan sebagaimana bidang pengembangan yang tertuang dalam Kurikulum 13 Pendidikan Anak Usia Dini.

Model permainan Ayo Kita Temukan bisa diterapkan untuk pembelajaran dengan beragam tema/subtema. Dan bagi lembaga pendidikan yang sudah menerapkan model pembelajaran area kegiatan belajar dan bermain bisa dilanjutkan di adalam area.

\section{Prosedur Permainan}

Langkah-langkah permainan Ayo Kita Temukan adalah sebagai berikut. (1) Guru menyiapkan media dan kelengkapan permainan. (2) Guru mengajak anak bercakap-cakap tentang tema dan subtema hari ini dan kegiatan yang akan dilakukan. (3) Guru menjelaskan tentang bermain “Ayo Kita Temukan” beserta aturan mainnya. (4) Guru membagi anakanak dalam kelas menjadi beberapa kelompok genap (satu kelompok terdiri dari 3-5 anak). Pembagian kelompok genap karena dalam satu putaran permaian, diikuti oleh 2 kelompok. (5) Berdasarkan subtema sesuai dengan Rencana Pelaksanaan Pembelajaran Harian (RPPH), guru menyebutkan ciri-ciri suatu benda atau hewan (yang telah disediakan dalam paket media permainan ini) kepada masing-masing kelompok, kemudian anak pada masing-masing kelompok menebaknya. (6) Anakanak pada masing-masing kelompok secara bergiliran mencari bentuk benda atau hewan yang dimaksud sebanyak-banyaknya di tempat yang sudah disediakan dan kemudian menempelkannya pada papan A-BACA dengan terlebih dahulu berjalan melewati halang rintang yang ada, bisa berjalan di atas "dingklik" atau berjalan berkelok-kelok melewati halang rintang yang lain misalnya traffic cone. (7) Guru menyampaikan kepada kelompok yang bermain bahwa objek yang dicari dan ditempelkan sudah ditemukan semua dan mempersilakan kelompok lain untuk menemukan huruf-huruf yang membentuk kata dari sebutan dari benda-benda atau hewan-hewan yang sudah ditemukan dan ditempel di papan A-BA-CA. Huruf-huruf yang sudah ditemukan selanjutnya ditempelkan pada papan A-BA-CA 
dan diletakkan di bawah bentuk benda atau hewan yang sudah tertempel di papan. (8) Anak-anak dari setiap kelompok secara bergiliran berjalan melewati halang rintang dan berusaha menemukan huruf-huruf (1 anak mencari 1 huruf saja) yang membentuk kata dari benda atau hewan dan selanjutnya menempelkannya pada papan A-BACA. (9) Guru dan anak-anak bertanya jawab tentang huruf-huruf yang dicari dan ditempelkan di papan. Anak-anak diminta mengitung jumlah benda atau hewan dan huruf-huruf yang membentuk kata. (10) Anak-anak dari kelompok lainnya secara bergiliran dan terlebih dahulu melewati halang rintang berusaha menemukan angka yang sesuai dengan jumlah benda atau hewan dan huruf-huruf yang tertempel dan juga menempelkannya pada papan A-BA-CA. (11) Guru memberikan tanda plus (+) atau minus (-) di antara kedua angka (milik masing-masing kelompok) dan anakanak secara bersama-sama menghitung hasilnya. (12) Untuk TK atau RA yang sudah memiliki fasilitas pembelajaran model area kegiatan bisa dilanjutkan di area-area. Anak- anak mendapatkan kertas yang ada gambar dari objek-objek yang sudah dicari dan ditempel di papan A-BACA. Sebagian anak diminta untuk mewarna gambar objek tersebut, sebagian lain diminta untuk menggunting, sebagian lain diminta untuk menulis kata dari nama atau sebutan objek tadi. (13) Setelah permainan selesai guru mengajak anak duduk bersama untuk melakukan recall terhadap permainan yang telah dilakukan. Ini bertujuan untuk memberikan penguatan kepada proses belajar yang telah dialami oleh anak saat melakukan permainan tadi.

\section{Uji Efektivitas Model Permainan}

Berdasarkan hasil validasi selanjutny model permainan diterapkan melalui eksperimen untuk diuji efektivitasnya. Eksperimen I dilakukan pada tanggal 2 Juni 2016 dengan subjek Anak Kelompok B1, B2, dan B3 TK Negeri Pembina Kota Kediri yang masing-masing kelompok berjumlah 22 anak (B1), 26 anak (B2), dan 24 anak (B3). Eksperimen II dilakukan pada tanggal 3 Juni 2016 di TK Dharma Wanita Kelurahan Ngampel Kota Kediri 
Pengembangan Model Permainan . . Sugiono, Kuntjojo

dengan subjek Anak Kelompok B1 yang berjumlah 20 anak dan Kelompok B2 yang berjumlah 19 anak.

Setelah eksperimen guru kelas melakukan penilaian kemampuan membaca, menulis, dan berhitung peserta didik. Hasil penilaian ini selanjutan dibandingkan dengan hasil penilaian sebelum model permainan diterapkan dalam pembelajaran. Untuk menganalisis data dipergunakan uji paired samples t test dan perhitungannya dilakukan menggunakan program SPSS 21.

Hasil analisis data kemampuan pra-membaca, pra-menulis dan berhitung 111 subjek penelitian dari TK Negeri Pembina Kota Kediri dan TK Dharma Wanita Ngampel Kota Kediri antara waktu sebelum dengan sesudah diterapkan model permainan dalam pembelajaran (perlakuan) disajikan berikut ini.

Nilai rata-rata kemampuan membaca sebelum perlakuan sebesar 2,82 dan nilai rata-rata sesudah perlakuan sebesar 3,29, artinya peningkatan kemampuan membaca setelah peserta didik diberi perlakuan berupa pembelajaran dengan model permainan. Untuk mengetahui apakah secara statistik terdapat perbedaan kemampuan membaca antara waktu sebelum dan sesudah perlakuan digunakan data hasil analisis paired samples test. Hasil analisis menunjukkan signifikansi 0,00 dan nilai ini lebih kecil dari nilai alfa $(0,05)$, hal itu bahwa model permainan efektif untuk meningkatkan kemampuan membaca.

Nilai rata-rata kemampuan menulis sebelum perlakuan sebesar 2,82 dan nilai rata-rata sesudah perlakuan sebesar 3,06. Untuk mengetahui apakah secara statistik terdapat perbedaan kemampuan menulis antara waktu sebelum dan sesudah perlakuan dengan signifikansi 0,00. Hasil analisis data tersebut menunjukkan bahwa model permainan efektif untuk meningkatkan kemampuan membaca.

Nilai rata-rata kemampuan berhitung sebelum peserta didik diberi perlakuan 2,97 dan sesesudah perlakuan sebesar 3,22 dengan nilai signifikansi $(0,00)$ lebih kecil dari nilai alfa $(0,05)$. Hasil analisis tersebut berarti bahwa model 
permainan efektif untuk meningkatkan kemampuan membaca.

\section{KESIMPULAN DAN SARAN}

Berdasarkan fokus permasalahan, temuan-temuan di lapangan, dan hasil pengembangan, dan hasil analisis data selanjutnya disimpulkan sebagai berikut.

1. Metode bermain yang digunakan para guru untuk mengembangkan kemampuan permulaan membaca, menulis dan berhitung Anak Kelompok B Taman Kanak-kanak adalah sebagai berikut.
(1) Metode bermain yang digunakan untuk mengembangkan
kemampuan permulaan membaca adalah bermain susun huruf, bermain susun kata, bermain tebak kata, dan bermain ular tangga.
(2) Metode bermain yang digunakan guru untuk mengembangkan
kemampuan permulaan menulis adalah bermain salin label, bermain eksplorasi kata, bermain

putaran huruf, dan bermain dadu engklek.

(3) Metode yang bermain yang digunakan guru untuk mengmbangkan kemampuan permulaan berhitung adalah bermain balok hitung, bermain dadu engklek, bermain putaran angka, bermain berhitung barang-barang yang ada di lingkungan belajar, bermain tebak angka, bermain hitung berantai, dan bermain ular tangga.

(4) Yang dijadikan pertimbangan para guru dalam memilih motode bermain yaitu: menyenangkan bagi anak, efektivitas, mudah dilakukan oleh anak, dan media serta alat permainan yang dibutuhkan mudah didapat atau dibuat.

2. Model permainan hasil penelitian dan pengembangan diberi sebutan "Bermain Ayo Kita Temukan". Secara teoristis model permainan ini bisa dinyatakan sebagai model yang 
Pengembangan Model Permainan . .

Sugiono, Kuntjojo

efektif untuk mengembangkan kemampuan pra-membaca, pramenulis, dan berhitung bahkan bisa juga untuk mengembangkan kemampuan yang lain yaitu: menyimak, berbicara, kemampuan, sain, fisik-motorik, dan juga sosial emosional anak usia dini. Model Bermain "Ayo Kita Temukan" dapat diterapkan dalam pembelajaran dengan berbagai tema/subtema.

3. Hasil uji efektivitas menunjukkan bahwa Model "Bermain Ayo Kita Temukan" sangat efektif untuk mengembangkan kemampuan permulaan membaca, dan berhitung peserta didik Kelompok B Taman Kanakkanak.

Berdasarkan temuan di lapangan selanjutnya disampaikan saran-saran sebagai berikut:

\section{Saran untuk para guru TK/RA}

Bahwa bermain bukan sekedar kegiatan selingan atau kegiatan yang bersifat rekreatif tetapi bermain merupakan metode pengembangan.
Oleh karena itu hendaknya pemilihan dan penerapan metode bermain dilakukan dengan pertimbangan utama faktor efektivitas.

Bahwa secara teoritis model permainan "Ayo Kita Temukan" dapat pula digunakan untuk mengembangkan kemampuankemampuan selain pra-membaca, pra-menulis, dan berhitung.

Untuk itu para guru TK/RA disarankan menerapkan model permainan tersebut untuk mengembangkan kemampuan anak misalnya kemampuan fisik-motorik atau sosial emosional.

2. Saran untuk pimpinan lembaga TK/RA

Bahwa kegiatan bermain akan dilakukan anak dengan baik yang pada akahirnya tujuan tercapai yaitu terjadinya perkembangan pada anak jika dilengkapi dengan alat-alat permainan edukatif. Berkenaan dengan hal tersebut maka disarankan kepada para pimpinan TK/RA untuk melengkapi sarana sekolah dengan alat-alat permainan edukatif yang fungsional untuk perkembangan anak. 


\section{DAFTAR PUSTAKA}

Aistear. (2013) Learning and Developing Through Play. http: ncca.biz/Aistear/pdf/ Guidelines _ENG/ Play_ENG.pdf. Diunduh pada tanggal 25 Februari 2015.

Departement for Children, Schools and Families. (2009) Learning, Playing and Interacting. Nottingham: Crown.

Direktorat Pembinaan Pendidikan Anak Usia Dini. (2015) Kurikulum Pendidikan Anak Usia Dini: Apa, Mengapa, dan Bagaimana. Jakarta: Kementrian Pendidikan dan Kebudayaan.

Dasar dan Struktur Kurikulum 2013 Pendidikan Anak Usia Dini. Jakarta: Kementrian Pendidikan dan Kebudayaan.

Goldstein. (2012) Play in Children's Development, Health and Wellbeing. Brussels: Toy Industries of Europe.

Gray, Peter. The Decline of Play and the Rise of Psychopathology in Children and Adolescents. American Journal of Play, volume 3, number 4. (C) 2011.
Latif, Mukhtar dkk. (2013) Orientasi Baru Pendidikan Anak Usia Dini: Teori dan Aplikasi. Jakarta: Kencana.

Montolalu (2005) Bermain dan Permainann Anak. Jakarta: Penerbit Universitas Terbuka.

Russ, Sandra W. (2004) Play in Child Development and Psychotherapy. London: Lawrence Erlbaum Associates.

Sugiyono. (2013) Metode Penelitian Kuantitatif Kualitatif dan $R \& R$. Bandung: Alfabeta.

Sujiono, Yuliani Nurani. (2009) Konsep Dasar Pendidikan Anak Usia Dini. Jakarta: PT Indeks.

Sukmadinata, Nana Syaodih. (2012) Metode Penelitian Pendidikan. Bandung: PT Remaja Rosda Karya.

Whitebread, David. (2012) The Importence of Play. Brussel: TIE.

White, Rachel E. (2012) The Power of Play: A Research Summary on Play and Learning. St. Paul: MCM.

Wikipedia. (2015) Model. Tersedia pada: https://id.wikipedia.org/wiki/Mo del. Diakses pada tanggal 6 Agustus 2015. 